\title{
Relationship between liveweights, linear body measurements and cost prices of small ruminants sold in and around mubi environs, adamawa state, Nigeria
}

\begin{abstract}
This study was conducted to investigate the relationship between body length(BL), heights at withers (HW), girth circumference (GC), Height at rump(HR), abdominal circumference $(\mathrm{AC})$ neck length $(\mathrm{NL})$, neck circumference $(\mathrm{NC})$ with live weights and cost prices of animals. Data obtained were subjected to Analysis of Variance (ANOVA), Multiple Correlation and Regression Analysis using SAS (2001) package. Where significant differences occurred among means, Duncan Multiple Range Test was used to separate them. It was found that length of animal (LA), girth circumference $(\mathrm{GC})$ and neck circumference $(\mathrm{NC})$ had highly positive significant $(\mathrm{P}<0.01)$ influences on weight while heights at rump (HR) and abdominal circumference (AC) had significant $(\mathrm{P}<0.05)$ influences on weight of the animals. However, there was no significant $(\mathrm{P}>0.05)$ correlation between height at wither $(\mathrm{HW})$ and neck length $(\mathrm{NL})$ with weight. The $\mathrm{R}^{2}$ value was $92.23 \%$, all their F-ratios were highly significant at $(\mathrm{P}<0.01)$, confirming the significance of these variables on the prices of the animals. It could be concluded that the price of sheep and goat breeds is subject to the weight. The price of sheep and goats in an open market can best be predicted from a combination of leg length and loin girth. Body conditions and market demand mainly determined goat and sheep price estimation in the areas.
\end{abstract}

Keywords: live weight, linear body measurements, cost prices, small ruminants
Volume 7 Issue 6 - 2018

\author{
Babale DM,' Abaya U Hussein, ${ }^{2}$ Gworgwor \\ $\mathrm{Z}^{3}$ \\ 'Department of Animal Production,Adamawa State University, \\ Nigeria \\ Maiha Local Government, Maiha, Adamawa State, Nigeria \\ ${ }^{3}$ Department of Animal Science and Range Management, \\ MAUTECH, Nigeria
}

Correspondence: Babale DM, Department of Animal
Production, Adamawa State University, Mubi, Nigeria,Tel
+07033749|7|/07088|47216, Email babeled@yahoo.com

Received: September 28, 2018 | Published: December 12, 2018

\section{Introduction}

Ruminants play an important role in the livelihood of farmers in developing world, providing sustenance as milk and meat, animal traction, manure for crop production, cash income from sales of their products as well as capital assets to face risks and misfortunes in harsh times or periods. ${ }^{1}$ According to Chineke et al., ${ }^{2}$ small ruminants (sheep and goats) have been reported to enjoy a unique position among other domestic animals reared by man not only as meat suppliers to the teaming population especially in the rural areas but for their contribution mainly to peasant farmers or household economy in the rural areas. Umar et al., ${ }^{3}$ stated that our livestock industry requires a properly functioning marketing organizational structure to achieve more efficient production and consumption decisions. Body weight is the commonly reported measure of size. ${ }^{4}$ Growth is one of the important selection criteria for the improvement of meat animals such as cattle, sheep and goats (Oni et al., 2011). The authors reported that measurement of growth are usually concerned with increase in size or body weight at a given age, especially weaning or yearling. Weighing bridges serve as the most reliable means of measuring live weight changes. However, recent studies have shown that body measurements could serve either to supplement body weight as a measure of productivity $^{5}$ or as predictor of some less visible characteristics (Berge, 2007). The marketing of small ruminants has not made headway because of the basic problem of unequal bargaining powers of various links in the marketing chain. ${ }^{6}$ There is therefore a call for structural reorganization of the Marketing system. ${ }^{1}$ The reliability of single measurements such as wither heights, body length, heart girth, rump height and width in the estimation of weight at both traditional and institutional levels have become widely necessary. ${ }^{7}$ Others have used it as indicators of breed origin and relationship within species. ${ }^{8}$ Body dimensions in different livestock species have been studied by many scientists. Therefore the assessments of the powers of body measurements in the estimation of weights and the accuracy of body weights in the estimation of size have been reported. ${ }^{7}$ The ability of the producers and buyers to relate the live animal measurements to growth characteristics is essential for optimum production and value based trading system. ${ }^{9}$ According to Akpa et al., ${ }^{10}$ growth is the sum total of increase in size of different structural body components measured from gain in body weight and linear body measurements. Adewumi et al., ${ }^{11}$ also stated that the ability of the producers and buyers of livestock to relate live animal measurements to live weights is of immense financial contribution to livestock production enterprise. That the ability of the producers and buyers of livestock to relate live animal measurements to growth characteristics, meat and milk production is essential for optimum production and value based trading systems. ${ }^{5}$ Body dimensions have been used in estimating body weight and appropriate pricing of meat animals. ${ }^{12}$ The authors further stated that body measurements on most farms in the tropics help farmers who lack weighing scales and the education to understand how to manipulate them. It is used in estimating weight and market value in terms of cost of the animals. Prasad et al., ${ }^{13}$ reported that body weight can be estimated by body measurements. That knowing the weight of the animal is important for computation of balanced ration, determination of growth and check on health of animal. The biometric parameters commonly used in predicting body weight (BW) in small 
ruminants include: body length (BL), Chest girth (CG) and height at withers (HW). ${ }^{12}$ The research was therefore carried out to determine linear body measurements of small ruminants sold in Mubi and its environs, determine live weights of small ruminants sold in the study area and their prices and to determine the relationships between linear body measurements, live weights and prices of the animals.

\section{Materials and methods}

\section{Experimental site}

The research was carried out in ruminants markets in and around Mubi, Adamawa State, Nigeria. Mubi region lies on Latitude $90^{\circ} 11^{1}$ north of the equator and Longitude $13^{\circ} 45^{1}$ east of the Greenwich Meridian at an altitude of $696 \mathrm{~m}$ above sea level. It is bounded in the South and East by Republic of Cameroun. With land area of $4,728.77 \mathrm{~m}^{2}$ and population of $245,460 .{ }^{14}$ it is situated in the Sudan Savanna zone of Nigeria. The vegetation type is best described as Combretacious woodland savanna ${ }^{15}$ which consists of grasses or weeds and shrubs collectively making $70 \%$ of the entire vegetation. Some of these grasses, weeds and shrubs are used as animal feeds. The area has two distinct seasons. Rainy season lasts for four (4) months and dry season that lasts for eight (8) months. Annual rainfall ranges from 700-900 mm with peak in August. The area has minimum temperature of $12.7^{\circ} \mathrm{C}$ in January and maximum of $37^{\circ} \mathrm{C}$ in April. ${ }^{15}$

\section{Parameters determined}

Body parameters measured were body length (BL), heights at withers (HW), girth circumference (GC), Height at rump (HR), abdominal circumference (AC) neck length (NL), neck circumference (NC) with live weights and cost prices of animals. Live weight of each animal was determined by suspending the animal on a spring balance and weight of each animal taken and recorded. Price of each animal was determined by watching the buyers and sellers bargain until reaching at the final price of the animal. In determining body measurements, body length (BL) was measured using tape rule as the distance from the occipital protuberance to the base of the tail. Height at wither was obtained by using platform upon which each animal was placed. It was measured as the distance from the surface of the platform to the withers using a meter rule. Girth circumference was determined by taking the measurement of the circumference of the chest with a tape. Height at rump was measured as the distance from the surface of the platform to the rump using a measuring rule. Neck length was the distance from the lower jaw to the point of the shoulder using tape rule. Neck circumference was gotten by measuring the distance round the neck below the lower jaw using the tape rule.

\section{Data analysis}

Data obtained were subjected to Multiple Correlation and Regression Analysis using $\mathrm{SAS}^{16}$ package. Where significant differences occurred among means, Duncan Multiple Range Test ${ }^{17}$ was used to separate them.

\section{Results and discussion}

The correlation relationships between the linear body measurements and live weight of goats are presented in Table 1. It was found that length of animal (LA), girth circumference (GC) and neck circumference $(\mathrm{NC})$ had highly positive significant $(\mathrm{P}<0.01)$ influences on weight while heights at rump (HR) and abdominal circumference $(\mathrm{AC})$ had significant $(\mathrm{P}<0.05)$ influences on weight of the animals. However, there was no significant $(\mathrm{P}>0.05)$ correlation between height at wither (HW) and neck length (NL) with weight. The regression analysis of linear body measurements for goats is presented in Table 2 . The $\mathrm{R}^{2}$ value was $92.23 \%$ while the F-ratio, 10.74 was highly significant $(\mathrm{P}<0.001)$. Variables like heights at withers (HW), neck length (NL) and neck circumference (NC) were also highly significant $(\mathrm{P}<0.001)$. This confirms the relationship of the variables on live weights and prices of the animals. The regression results between linear body measurements and prices of animals showed a very highly $(<0.001)$ significant relationships between all linear body measurements and prices of goats. All their F-ratios are highly significant at $(\mathrm{P}<0.01)$, confirming the significance of these variables on the prices of the animals. The correlation relationship between body measurements and the live weights of sheep are presented in Table 3. It was found that all the linear body measurements except girth circumference had positive significant correlation with live weight. Neck circumference (NC), abdominal circumference (AC) and length of animal (LA) had highly positive and significant $(\mathrm{P}<0.001)$ influence on body weights. The regression analysis of linear body measurements for sheep is presented in Table 4 . The $\mathrm{R}^{2}$ value was $94.8 \%$ while the F-ratio, 16.26 was highly significant $(\mathrm{P}<0.01)$. Variables like heights at withers (HW), neck length (NL) and neck circumference $(\mathrm{NC})$ were highly significant $(\mathrm{P}<0.001)$. This also confirms the relationship of the variables on live weights and prices of the animals. The regression results between linear body measurements and prices of animals showed a very highly $(<0.001)$ significant relationships between all linear body measurements and prices of goats. All their F-ratios are highly significant at $(\mathrm{P}<0.01)$, confirming the significance of these variables on the prices of the animals. The correlation relationships between the linear body measurements and live weight of goats showed that length of animal (LA), girth circumference (GC) and neck circumference (NC) had highly positive significant $(\mathrm{P}<0.01)$ influences on weight while heights at rump (HR) and abdominal circumference (AC) had significant $(\mathrm{P}<0.05)$ influences on weight of the animals. However, there was no significant $(\mathrm{P}>0.05)$ correlation between height at wither (HW) and neck length (NL) with weight. Alemayehu and Tikabo (2010) found a very high $(\mathrm{P}<0.001)$ correlation relationship between girth circumference (GC), animal length (AL) and height at withers (HW) with live weight of animal. They found $\mathrm{R}^{2}$ of $63 \%$ for goats. They concluded that the higher correlation coefficient of body weight with a given body dimension demonstrate that on the basis of the dimensions of various measurements, the body weight could be predicted more accurately. That girth circumference is the best used for live weight estimation at farm conditions especially under smallholder farmers. The regression analysis of linear body measurements for goats revealed that the $\mathrm{R}^{2}$ value was $92.23 \%$ while the F-ratio, 10.74 was highly significant $(\mathrm{P}<0.001)$. Variables like heights at withers (HW), neck length (NL) and neck circumference (NC) were also highly significant $(\mathrm{P}>0.001)$. This confirms the relationship of the variables on live weights and prices of the animals. The regression analysis of linear body measurements for goats revealed that the $\mathrm{R}^{2}$ value was $92.23 \%$ while the F-ratio, 10.74 was highly significant $(\mathrm{P}<0.001)$. Variables like heights at withers $(\mathrm{HW})$, neck length (NL) and neck circumference (NC) were also highly significant $(\mathrm{P}>0.001)$. This confirms the relationship of the variables on live weights and prices of the animals. Hamayun et al., ${ }^{18}$ in a research to find the relationship between body weights and body linear dimensions found all values of body measurements to be higher in males than females. That body weight had positive and highly significant correlation $(\mathrm{P}<0.001)$ with body length $(0.49)$, height at withers $(0.75)$ and heart girth (0.64). The highest and significant correlation existed between live weight and girth circumference which eventually was taken over by body length with advance in age. The regression results between linear body measurements and prices of animals showed a very highly $(<0.001)$ significant relationships 
between all linear body measurements and prices of goats. All their F-ratios are highly significant at $(\mathrm{P}<0.01)$, confirming the significance of these variables on the prices of the animals. It is reported by Ramesh et al. ${ }^{19}$ that estimation of price in small ruminants while marketing is mainly based on the body condition and market demand. That body condition is judged by healthiness of animals, body configuration and average weight according to size and height. Dossa et al., ${ }^{20}$ found that selection criteria for small ruminants in Kano and her environs were health status of animal with body conformation being highly $(\mathrm{P}<0.001)$ significant that body size ranked significant at $(\mathrm{P}<0.05)$. Therefore, important criteria were related to physical appearance consisting of body size, apparent health and body conformation. Agajiye ${ }^{21}$ stated that in marketing of small ruminants, smallholders use visual observations and other proxy methods for estimation of weights and prices. By visual observation, they consider body condition and healthiness. Others are age of animals and temperament. Therefore smallholders are encouraged to improve body condition of their animals in order to attract higher premium prices for their animals. The correlation relationship between body measurements and the live weights of sheep was found that all the linear body measurements except girth circumference had positive significant correlation with live weight. Neck circumference (NC), abdominal circumference (AC) and length of animal (LA) had highly positive and significant $(\mathrm{P}<0.001)$ influence on body weights. The works of Afolayan et al., ${ }^{22} \&$ Otoikhian et al., ${ }^{23}$ reconfirmed all these findings. Afolayan et al. ${ }^{22}$ in estimating live weight from body dimensions of Yankasa sheep found that live weight was highly $(\mathrm{P}<0.001)$ correlated with girth circumference at 0.94 . Height, length and girth circumference of the animals were directly related to the size of the animals, hence, displayed moderate to very high positive correlations with one another $(0.79$ and 0.87$)$. In addition, the work of Otoikhian et al. ${ }^{23}$ on correlation of body weight and body dimensions of uda sheep under extensive management system found that distance between eyes, ear length and ear width, tail length and live weight increased progressively with age of the animal which eventually decreased with age beyond 25 months. They found that positive correlations were found between live weights of the animals and their linear dimension parameters. The regression analysis of linear body measurements for sheep shows the $\mathrm{R}^{2}$ value to be $94.8 \%$ with the F-ratio, 16.26 and is highly significant $(\mathrm{P}<0.01)$. It reported that the weight of sheep or goat fluctuates as a result of management system, pregnancy, gut fill and lactation. However, linear measurements are less affected by these factors and hence, allow for growth comparisons of different body parts at any stage or phase of growth. Hamayun et al., ${ }^{18}$ in a research to find the relationship between body weights and body linear dimensions found all values of body measurements to be higher in males than females. That body weight had positive and highly significant correlation $(\mathrm{P}<0.001)$ with body length $(0.49)$, height at withers (0.75) and heart girth (0.64). The highest and significant correlation existed between live weight and girth circumference which eventually was taken over by body length with advance in age. The regression results between linear body measurements and prices of animals showed a very highly $(<0.001)$ significant relationships between all linear body measurements and prices of goats. All their F-ratios are highly significant at $(\mathrm{P}<0.01)$, confirming the significance of these variables on the prices of the animals. Iyiola-Tunji et al. ${ }^{24}$ had found price to be positive and moderately correlated to back length $(57.5 \%)$, chest girth $(53.8 \%)$ height at withers $(53.5 \%)$ and leg length at $(\mathrm{P}<0.001)$. This shows that the longer the legs of the animal, the higher the height at withers and the higher the price. ${ }^{25}$ That height at withers (HW) together with animal length (AL) and girth circumference (GC) are the most important variables used to obtain up to $38 \%$ prediction of price for small ruminants. They therefore concluded that the price of small ruminants in an open market can best be predicted from a combination of leg length, girth circumference and loin girth. ${ }^{26}$ In summary, after subjecting the measured parameters to various correlation and regression analysis, the price was found to be positive and moderately correlated to back length, chest girth, height at withers and leg length at $(\mathrm{P}<0.001)$. This shows that the longer the legs of the animal, the higher the height at withers and the higher the price. That height at withers (HW) together with animal length (AL) and girth circumference (GC) are the most important variables used to obtain up to $38 \%$ prediction of price for small ruminants. Therefore the price of small ruminants in an open market can best be predicted from a combination of leg length, girth circumference and loin girth. In conclusion, since the body measurements had positive and high correlation with body weight indicating that body measurements can be used for estimation of body weight in the field where scales are not usually available. These may also be used as selection criteria. ${ }^{27}$ The live body weight of the sheep and goat breeds could be estimated based on the linear body measurements. Height at withers, girth circumference and neck circumference were found to be the best parameters to use for live weight estimation at farm conditions especially under the small holder farmers. This could be used for various purposes such as marketing, breeding and growth control. The price of sheep and goat breeds is subjected to the weight. The price of sheep and goats in an open market can best be predicted from a combination of leg length and loin girth. Body conditions and market demand mainly determined goat and sheep price estimation in the areas.

Table I Correlation relationships between live weights and body measurements of goats

\begin{tabular}{lllllllll}
\hline & HW & GC & L.Animal & HR & AC & NL & NC & LVW \\
\hline HW & & $0.074^{\text {ns }}$ & $0.188^{* *}$ & $0.372^{* *}$ & $0.221^{* *}$ & $-0.032^{\text {ns }}$ & $0.127^{* *}$ & $0.247^{* *}$ \\
$\mathbf{G C}$ & $0.074^{* * *}$ & & $0.04^{\text {ns }}$ & $0.023^{\text {ns }}$ & $0.164^{* *}$ & $0.126^{* *}$ & $0.04^{\text {ns }}$ & $0.012^{\text {ns }}$ \\
L.An & $0.188^{* *}$ & $0.04^{\text {ns }}$ & & $0.703^{* *}$ & $0.228^{* *}$ & $0.745^{* *}$ & $0.401^{* *}$ & \\
HR & $0.372^{* *}$ & $0.023^{\text {ns }}$ & $0.562^{* *}$ & & $0.411^{* *}$ & $0.140^{* *}$ & $0.436^{* *}$ & $0.278^{*}$ \\
AC & $0.221^{* *}$ & $0.164^{* *}$ & $0.703^{* *}$ & $0.411^{* *}$ & & $0.193^{* *}$ & $0.713^{* *}$ & $0.364^{* *}$ \\
NL & $-0.032^{\text {ns }}$ & $0.126^{* *}$ & $0.228^{* *}$ & $0.140^{* *}$ & $0.193^{* *}$ & & $0.172^{* *}$ & $0.228^{* *}$ \\
NC & $0.127^{* *}$ & $0.040^{\text {ns }}$ & $0.745^{* *}$ & $0.436^{* *}$ & $0.713^{* *}$ & $0.172^{* *}$ & & $0.442^{* *}$ \\
LVW & $0.247^{* *}$ & $0.012^{\text {ns }}$ & $0.401^{* *}$ & $0.278^{* *}$ & $0.364^{* *}$ & $0.228^{* *}$ & $0.442^{* *}$ &
\end{tabular}

HW, Height at withers; GC, Girth circumference; LA, Length of animal; HR, Height at rump; AC, Abdominal circumference; NL, Neck length; NC, Neck circumference; and LVW, Live weight; 
Table 2 Regression result for goats

\begin{tabular}{lllll}
\hline Parameters & Coefficient & Standard error & t-value & Significance \\
Constant & -6582.83 & 8020.2 & -0.821 & $* * *$ \\
HW & -83.59 & 361.04 & 0.232 & $* * *$ \\
GC & -194.5 & 199.58 & -975 & $* * *$ \\
HR & 616.92 & 693.55 & 890 & $* * *$ \\
NL & 626.65 & 392.32 & -1.597 & $* * *$ \\
NC & 599.15 & 430.28 & 1.392 & $* * *$ \\
AC & -635.95 & 323.35 & -1.967 & $* * *$ \\
Fore leg length & 249.08 & 1347.76 & 0.185 & $* * *$ \\
Hind leg length & -775.71 & 1076.5 & -0.721 & $* * *$ \\
AL & 859.1 & 647.27 & 1.327 & $* * *$ \\
WT.ANIM & 453.35 & 168.39 & 2.692 & $* * *$ \\
R2 & 92.23 & & & \\
F & $10.74 * * *$ & & & \\
\hline
\end{tabular}

Dependent variable: Price

Table 3 Correlation relationships between live weights and body measurements of sheep

\begin{tabular}{|c|c|c|c|c|c|c|c|c|}
\hline & HW & GC & L.Animal & HR & $A C$ & NL & NC & LVW \\
\hline HW & & $0.74 I^{* * *}$ & $0.694 * *$ & $0.372^{* *}$ & $0.221 * *$ & $-0.032^{\text {ns }}$ & $0.127^{* *}$ & $0.712 * *$ \\
\hline GC & $0.74 I^{* * * *}$ & & $0.04^{\text {ns }}$ & $0.023^{\text {ns }}$ & $0.164 * *$ & $0.126 * *$ & $0.04^{\text {ns }}$ & $0.673 * *$ \\
\hline L.An & $0.694^{* *}$ & $0.04^{\text {ns }}$ & & $0.562 * *$ & $0.703 * *$ & $0.228 * *$ & $0.745^{* *}$ & $0.493 * *$ \\
\hline$H R$ & $0.372 * *$ & $0.023^{\text {ns }}$ & $0.562 * *$ & & $0.4 I I * *$ & $0.140 * *$ & $0.436 * *$ & $0.278^{*}$ \\
\hline$A C$ & $0.221 * *$ & $0.164^{* *}$ & $0.703 * *$ & $0.4 \mathrm{I}$ I** & & $0.193 * *$ & $0.713^{* *}$ & $0.364 * *$ \\
\hline NL - & $0.032^{\mathrm{ns}}$ & $0.126 * *$ & $0.228^{* * *}$ & $0.140 * *$ & $0.193 * *$ & & $0.172 * *$ & $0.228 * *$ \\
\hline $\mathrm{NC}$ & $0.127 * *$ & $0.040^{\text {ns }}$ & $0.745^{* *}$ & $0.436 * *$ & $0.713 * *$ & $0.172^{* *}$ & & $0.442 * *$ \\
\hline LVW & $0.712 * *$ & $0.673 * *$ & $0.401 * *$ & $0.278 * *$ & $0.364 * *$ & $0.228 * *$ & $0.442 * *$ & \\
\hline
\end{tabular}

**Significant at $5 \% \mathrm{~ns}$, Not significant;

HW, height at withers; GC, girth circumference; LA, length of animal; HR, height at rump;AC, abdominal circumference; NL, neck length; NC, neck circumference; and LVW, live weight

Table 4 Regression result for sheep

$\begin{array}{lllll}\text { Parameter } & \text { Coefficient } & \text { Standard error } & \text { t-value } & \text { Significance } \\ \text { Constant } & -6198.99 & 6017.14 & -1.03 & * * * \\ \text { HW } & -796.64 & 910.65 & -0.875 & * * * \\ \text { GC } & 470.92 & 235.68 & 1.998 & * * * \\ \text { HR } & 214.57 & 677.24 & 0.317 & * * * \\ \text { NL } & 643.22 & 564.36 & 1.14 & * * * \\ \text { NC } & 629.06 & 328.9 & 1.913 & * * * \\ \text { AC } & 234.53 & 166.15 & -1.412 & * * * \\ \text { FR.LG.LTH } & 1369.15 & 1557.72 & 0.879 & * * * \\ \text { HN LG LTH } & -1336.43 & 1324 & -1.009 & * * * \\ \text { AL } & 48.5 & 242.43 & 0.2 & * * * \\ \text { WT AN } & 261.77 & 131.37 & 1.993 & * * * \\ \text { R2 } & 94.8 & 16.26 * * * & & \end{array}$

$* * *$ Significant at $1 \% * *$ Significant at $5 \%$ ns not significant

Dependent variable: Price

Citation: Babale DM, Hussein AU, Gworgwor Z. Relationship between liveweights, linear body measurements and cost prices of small ruminants sold in and around mubi environs, adamawa state, Nigeria.J Dairy Vet Anim Res. 2018;7(6):273-277. DOI: I0.15406/jdvar.2018.07.00226 


\section{Conclusion and recommendations}

From the findings of this research, it could be concluded that the prices of sheep and goat breeds are subject to the weights. The prices of sheep and goats in an open market can best be predicted from a combination of leg length and loin girth. Body conditions and market demand mainly determined goat and sheep price estimations in the areas. It is recommended that in the absence of weighing scales, rules could be used to estimate weights through body measurements for better pricing of small ruminants.

\section{Acknowledgments}

None

\section{Conflicts of interest}

The author declares that there are no conflicts of interest.

\section{References}

1. Lamidi AA. Utilization of Panicum maximum (Jacq), Gliricidia sepium (Jacq) and G melina arborea (Rocb) supplemented as Dry season feed for West African Dwarf goats. A PhD Thesis of University of Agriculture, Abeokuta, Ogun State. 2009

2. Chineke CA, Adebayo JO, OB Morenkeji. Relationship between some Morphometric variables of W.A.D. Village Goats in South West Nigeria. 2010 .

3. Umar AM, Kazaure L. Socio-economic Characteristics of goat Traders and Marketing activities in Hadeja, Jigawa State, Nigeria. Proceedings of Animal Science Association of Nigeria (ASAN) conference held at Abuja $9^{\text {th }}-13^{\text {th }}$ September. 2012;254-256.

4. Fitzhugh HA, GE Bradford. Hair sheep of West Africa and Americas. Westview Press: Boulder, Co. 2003.

5. Afolayan RA, Pitchford WS, Weatherly AW, et al. Genetic variation in growth and Body Dimensions of Jersey and Limousin Crossbred Cattle. Asian-Austral Journal of Animal Science. 2002;15(10):1378-1385.

6. Adamu MA. Beef Production in Nigeria, Status, Problems and Prospects. Proceedings of Workshop held at Jos, Nigeria $23^{\text {rd }}-25^{\text {th }}$ June. 2002.

7. Adejoro FA, Salako AE, AA. Ogundere. Phenotypic Characterization of the Balami Sheep in Nigeria. Journal of Animal Science. 2018;20(2):76-79.

8. Jewel BS. Cattle from British Archeological site. Royal Archeology Institute London. 2003.

9. Samuel OKF, AE Salako. Body Measurements characteristics of the West African Dwarf goats in Deciduous forest zone of South Western Nigeria. African Journal of Biotechnology. 2008;7(14).

10. Akpa GN, Suleiman IO, Alphonsus C. Effect of Age, Hair type and Body Condition score on body conformation traits in Yankasa Rams. Nigeria Journal of Animal Science. 2011;13:23-28.

11. Adewumi OO, E.S. Adewole. Milk off take of Dam, Neck and Cephalic Measurements in Lambs and kids under traditional system of Management. Proceedings of the $16^{\text {th }}$ Annual Conference of Animal Science Association of Nigeria (ASAN) 12 ${ }^{\text {th }}-15^{\text {th }}$ September, 2011. 2012.
12. Eghahi JO, Dim NJ, Mabrama BD. Body Weight and Body Dimensions in Free Range West African Dwarf Goats in the Guinea Savanna. Proceedings of the $16^{\text {th }}$ Annual Conference of Animal Science Association of Nigeria (ASAN) 12 $2^{\text {th }}-15^{\text {th }}$ September, 2011. 2011.

13. Prasad J. Goat, Sheep and Pig Production and Management, $4^{\text {th }}$ Edition Kalyani Publishers, Daryagani. New Delhi. 2010.

14. Saidu I, Gadiga BL. Population: A write up in Mubi region a geographical synthesis by Adebayo AA. Department of geography, Federal University of Technology, Yola. Published by Paraclette Publishers, Yola 2004;117-119.

15. Adebayo AA. Mubi Region: A geographical synthesis. Yola, Nigeria. 2004.

16. SAS. Statistical Analysis System, SAS 2001, SAS/STAT Software Release 8.02, SAS Institute Inc. Cary, NC. USA. 2001.

17. Duncan DB. Multiple Ranges and Multiple F-tests Biometrics. 1955;11(1):1-42.

18. Hamayun K, Fida M, Ahmad R, et al. Relationship of Body weight with Linear Body Measurements in Goats. Journal of Agriculture and Biological Science. 2006;1(3).

19. Ramesh D, Meena HR, KL Meena. Analysis of Small Ruminant Market system Different Agro-climatic zones of Southern India. Veterinary World. 2011;5(5):288-293.

20. Dossa LH, Mamadou S, Andreas B, et al. Production objectives and Breeding Practices of Urban Goats and Sheep Keepers in West Africa: Regional Analysis and Implications for the Development of supportive breeding programs. Spring open Journal. 2015;19(4).

21. Agajiye T. Demand influencing Attributes in the Smallhoder Livestock Marketing Practices. Livestock Research for Rural Development. 2010;22(11).

22. Afolayan RA, Adeyinka IA, CAM Lakpini. Predictions of Live weight from Objective live weight Dimension traits in Yankasa Sheep. Proceedings of the $31^{\text {st }}$ Annual Conference of the Nigerian Society of Animal Production (NSAP). 2006.

23. Otoikhian CSO, Otoikhian AM, Akporhuaro N, et al. Correlation of Body Weight and Some Body Measurement Parameters in Ouda sheep Under Extensive Management systems. African Journal of General Agriculture. 2008.

24. Iyiola-Tunji AO, Olugbemi TS, Ali AO, et al. Inter-relationship Between Body Measurements and prices of sheep in open Markets in Kano State (2011). Animal Production. 2013;13(1):64-68.

25. Areola OO. Soil and Vegetable Resources in: Geography of Nigeria Dev Heinemann, Ibadan. 1983.

26. Adejoro FA, Salako AE, AA Ogundere. Phenotypic Characterization of the Balami Sheep in Nigeria. Proceedings of the $15^{\text {th }}$ Annual conference of Animal Science Association of Nigeria (ASAN) held at University of Uyo, $13^{\text {th }}-16^{\text {th }}$ September, 2010

27. Alemayehu T, G Tikabo. Application of Linear Body measurements for live body weight estimation of highland sheep in Tigray Region, NorthEthiopia. Journal of the Dry lands. 2010;3(2):203-207. 